\title{
Kajian Arsitektur Pada Massa Bangunan Masjid Cipaganti
}

\author{
Andiyan ${ }^{1 *}$, Irfan Aldyanto ${ }^{1}$ \\ ${ }^{1}$ Program Studi Arsitektur,Fakultas Sains dan Teknik, Universitas Faletehan \\ "Korespondensi: andiyanarch@gmail.com
}

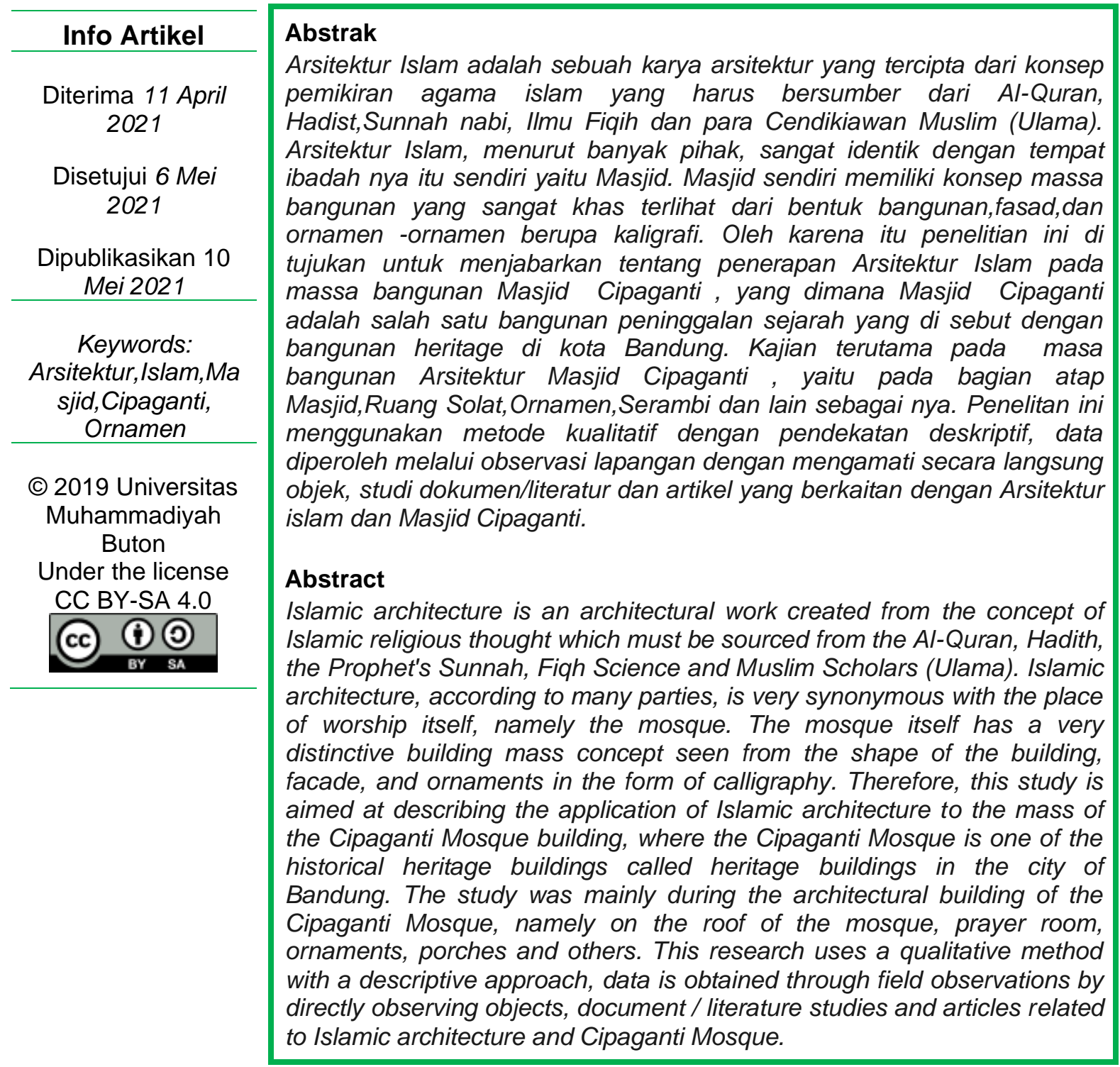




\section{Pendahuluan}

Arsitektur menurut Rapoport (1969) merupakan ruang tempat hidup manusia, yang lebih dari hanya sekedar fisik, namun juga menyangkut pada pranata budaya dasar. Pranata tersebut kemudian meliputi seperti tata atur kehidupan sosial serta juga budaya Masyarkat, yang kemudian diwadahi serta sekaligus mempengaruhi arsitektur.

Salah satu konsep arsitektur yang mempengaruhin kebudayaan dan kehidupan sosial adalah Arsitektur Islam .Pada dasar nya Arsitektur Islam berpedoman kepada Al-Quran dan Hadits, seperti yang di jelaskan dalam hadits seperti berikut "Dari Katsir bin Abdullah dari ayahnya dari kakeknya RA, ia berkata : Rasulullah SAW pernah bersabda : "Aku telah meninggalkan pada kamu sekalian dua perkara yang kamu tidak akan sesat selama kamu berpegang teguh kepada keduanya, yaitu : Kitab Allah dan Sunnah Nabi-Nya”. [HR. Ibnu Abdil Barr] .

Dari dalil tersebut bisa di pastikan bahwa konsep arsitektur Islam tidak boleh bertentangan dengan keduanya . Arsitektur Islam sendiri identik dengan bangunan tempat peribadahan yaitu Masjid .Masjid yang terkenal di kota Bandung yang menggabungkan beberapa gaya Arsitektur Tradisional jawa dan gaya Eropa dengan menerapkan konsep Arsitektur Islam adalah Masjid Cipaganti .

Masjid Cipaganti adalah salah satu bangunan cagar budaya atau bangunan peninggalan sejarah yang berada di daerah Bandung Utara. Masjid ini di bangun pada tanggal 7 Februari 1933 oleh Arsitek berkebangsaan Belanda Prof. C.P. Wolff Schoemaker. Selain sebagai sarana peribadatan, Masjid Cipaganti ini juga bisa di gunakan sebagai sarana pembelajaran sejarah. Masjid ini pernah mengalami beberapa kali renovasi perluasan bangunan di karenakan jamaah Masjid yang terus bertambah banyak. Masjid ini merupakan bangunan satu lantai yang terdiri dari satu massa bangunan lama dan satu massa bangunan baru. Bangunan Masjid ini memiliki bentuk persegi panjang ke arah selatan dan utara. Masjid Cipaganti memiliki kubah berbentuk limasan yang terdiri dari satu undakan dan penambahan satu kubah kecil yang berada di ujung atas pada kubah limasan. Selain itu Masjid Cipaganti memiliki ornamen yang unik pada bagian dalam Masjid dimana ornamen tersebut adalah kaligrafi yang di terapkan pada bagian interior Masjid Cipaganti.

Dari beberapa keunikan yang di miliki Masjid Cipaganti, mulai dari bentuk massa dan ragam langgam Arsitektur yang di terapkan pada Masjid ini ,maka layak untuk di jadikan sebagai objek kajian/penelitian .

\section{Metode Penelitian}

Metode Penelitian yang di gunakan dalam penelitian ini adalah dengan menggunakan metode penelitian kualitatif dengan pendekatan dekstriptif. Dalam peneleitian ini peneliti menggunakan membagi menjadi beberapa tahapan tahapan yaitu observasi, dokumentasi dan analisa Data.

Pada tahap observasi dan dokumentasi ini penulis melakukan survey ke lokasi Objek penelitian yaitu Masjid Cipaganti untuk mengamati secara langsung karakteristik Massa bangunan, Orientasi bangunan, fungsi dan elemen ruang pada Masjid tersebut. Setelah itu adalah melalukan Studi literlatur pada artikel dan jurnal yang terkait dengan Massa bangungan, Arsitektur islam dan informasi yang berkaitan dengan penelitian ini. Dari data yang telah di kumpulkan selanjutnya 
melakukan analisa dengan membandingkan Teori yang sudah di jelaskan sebelum nya dengan analisa yang di temukan pada objek penelitian tersebut. Setelah itu masuk ke dalam tahap pembahasan yang akan menjelaskan tentang permasalahan- permasalahan yang terdapat pada objek dan di harapkan dapat di temukan solusi dan kesimpulan dari penelitian tersebut (Sugiyono, 2014).

\section{Hasil dan Pembahasan}

Masjid ini berada di wilayah Bandung Utara, yang dulu merupakan komplek pemukiman bangsa Eropa. Masjid Raya Cipaganti di desain oleh Prof. Kemal C.P. Wolff Shoemaker, seorang arsitek Belanda yang menjadi Profesor di ITB Bandung. Bangunan dengan luas tanah $2675 \mathrm{~m} 2$ (dua ribu enam ratus tujuh puluh lima) sedangkan luas bangunan nya $1.067 \mathrm{~m} 2$ (seribu enam puluh tujuh). Cara ini sebenarnya dapat mengurangi tingkat subsidi operasional, dengan mengajak operator pihak swasta untuk mengatur layanan kereta api penumpang, dengan salah satu kriteria penyeleksian adalah subsidi yang dibutuhkan.(Andiyan, Rachmat, 2021)

Masjid ini merupakan bangunan satu lantai yang terdiri dari satu massa bangunan lama atau cagar budaya dan satu massa bangunan baru ini memiliki banyak hal hal yang perlu di bahas terutama tentang apa saja konsep Arsitektur Islam yang di terapkan pada massa bangunan Masjid tersebut secara lebih dalam.

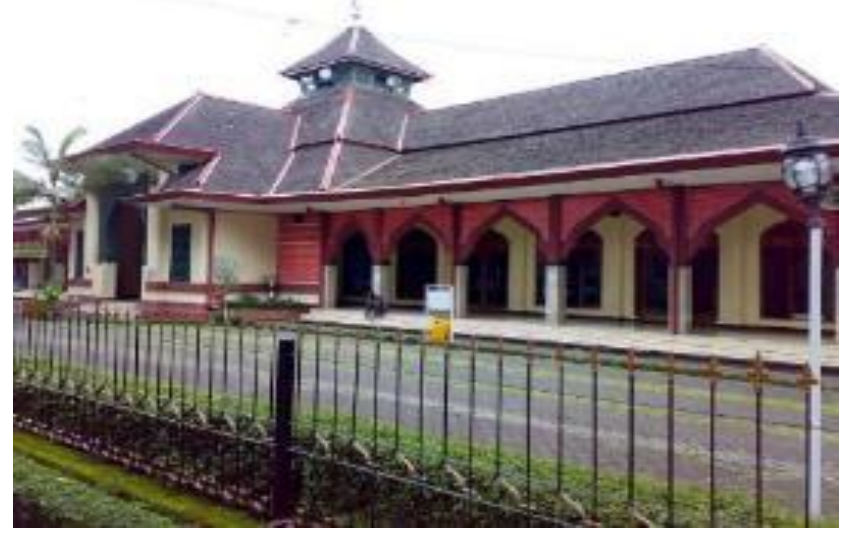

Gambar 1. Prespektif Masjid Cipaganti. Sumber:

(https://simas.kemenag.go.id/index.php/profil/Masjid/512/\#content-sejarah)

\subsection{Massa Bangunan Masjid}

Massa bangunan Masjid CIPAGANTI terdiri dari satu massa bangunan lama atau yang di sebut dengan bangunan cagar budaya dan satu massa bangunan baru.

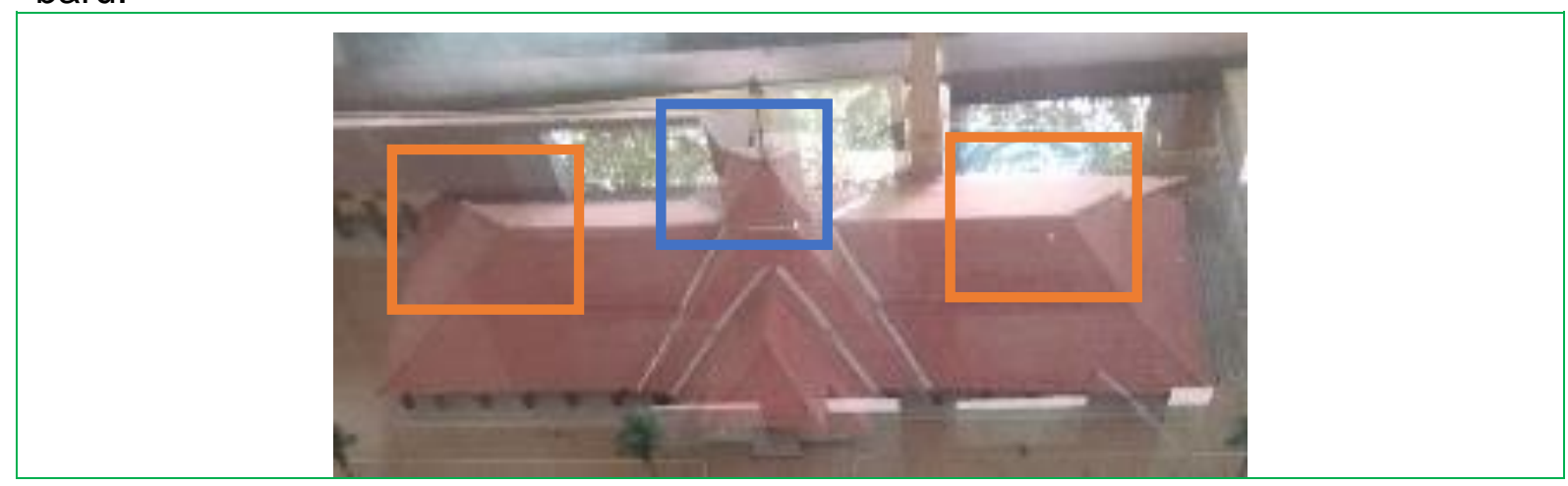


Gambar 2. Maket Masjid Cipaganti. Sumber: Dokumentasi Pribadi

Sesuai dengan aturan yang diterapkan dalam islam bahwa posisi mihrab atau posisi mimbar pada bagian Masjid harus lah berada di tengah seperti yang di jelaskan dalam sabda nabi Diriwayatkan dari Abu Hurairah katanya: Rasulullah saw besabda: "Jadikan imam di tengah (saf) dan penuhilah (saf) yang kosong". [HR. Abu Dawud].dan di lihat dari gambar di atas posisi mihrab dan mimbar berada di tengah tengah bangunan tempat solat yang bertepatan pada bangunan utama atau bangunan cagar budaya . maka dapat di tarik kesimpulan bahwa massa bangunan Masjid Cipaganti sudah sesuai dengan aturan Arsitektur Islam yang berlaku karna Arsitektur Islam adalah sebuah pendekatan arsitektur dengan berusaha melihat ke dalam sistem nilai yang ada dalam Islam untuk kemudian diterapkan ke dalam perancangan bangunan (Utaberta, 2007).

\subsection{Orientasi Massa bangunan}

Konsep umum bangunan ini yaitu mampu meciptakan harmoni antara fungsi utama bangunan Konvesi dan Eksibisi dengan penerapan konsep arsitektur kontemporer(Tiaratanto, Excya,Affandi,Kemal, 2021).Seperti yang di jelaskan di bab sebelum nya bangunan Arsitektur Islam seperti bangunan Masjid ini berporientasi ke arah ka'bah atau jika menurutt arah angin adalah arah barat .seperti yang di jelaskan oleh Majelis Ulama Indonesia (MUI) sudah mengeluarkan fatwa tentang arah kiblat. Bagi umat Islam di Indonesia, salatnya sudah sah dengan menghadap ke arah barat, mengingat letak geografis Indonesia yang berada di timur kabah. Dan dalam analisa di atas bangunan Masjid Cipaganti ini menghadap ke arah barat dengan bentuk massa memanjang dari arah selatan ke arah utara .(Irawan \& Muqoffa, 2019). Sedangkan maksud dari pekerjaan ini adalah tercapainya kehidupan masyarakat yang sehat dan layak huni di kawasan tersebut:(Andiyan, Indra, 2018)

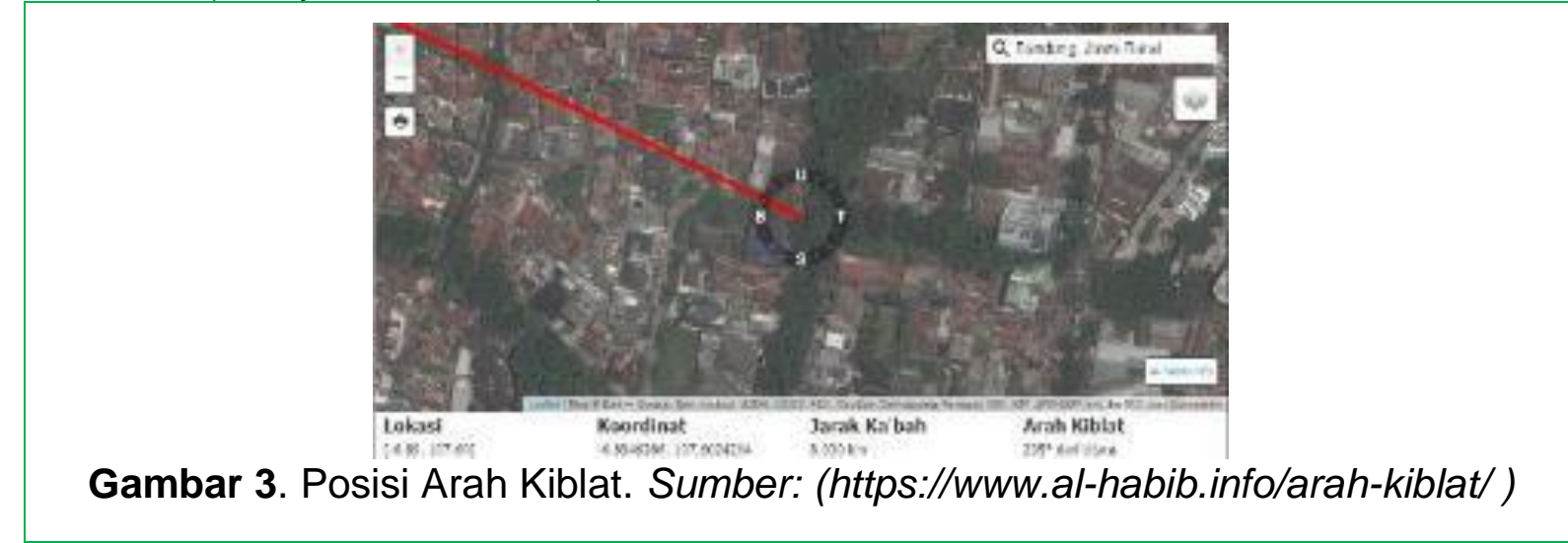




\section{Gambar 4. Posisi Arah Kiblat. Sumber: Google Earth}

Jika dilihat dari gambar di atas orientasi bangunan Masjid CIPAGANTI tidak tegak lurus ke arah barat melainkan agak miring ke arah utara .dan juga jika di lihat dari gambar arah angin di atas maka orientasi bangunan Masjid dan arah kiblat ini 290 derajat dari Utara.

\subsection{Elemen dan fungsi ruang Masjid Cipaganti}

Sesuai dengan teori yang sudah di jelaskan pada bab sebelum nya semua masjid memiliki elemen dan fungsi ruang yang sama dan semua ruang ruang tersebut memiliki aturan nya masing-masing Dari mulai ruang solat, ruang mimbar dan mihrab,tempat wudu,serambi masjid,dan lain lain.

a. Ruang Shalat

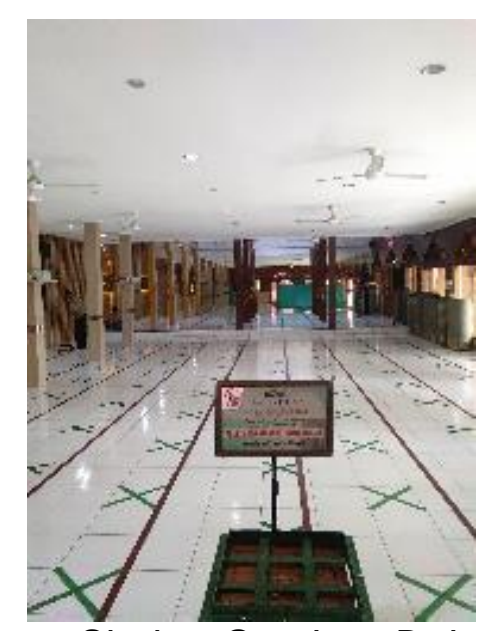

Gambar 5. Ruang Shalat. Sumber: Dokumentasi Pribadi

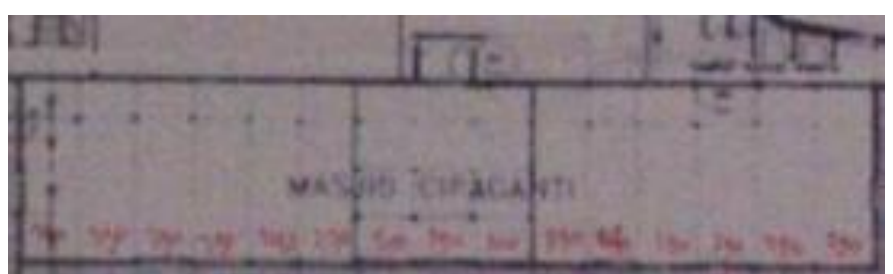

Gambar 6. Denah Ruang Shalat. Sumber: Dokumentasi DKM Masjid Cipaganti

Ruang solat Masjid Cipaganti ini memiliki bentuk memanjang seperti yang terlihat di gambar di atas. Ruang solat ini terbagi menjadi ruang solat untuk imam 
dan untuk ma'mum. Untuk ma'mum solat itu sendiri di bagi menjadi dua yaitu ma'mum laki-laki dan ma'mum perempuan.

b. Mihrab dan Mimbar

Mihrab dan mimbar pada Masjid Cipaganti ini berletak di tengah tengah. Mihrab yang berada di bagian tengah bangunan asli atau bangunan cagar budaya dari Masjid Cipaganti.(Mujab, 2014)

Gambar 7. Denah Masjid. Sumber: Dokumentasi DKM Masjid Cipaganti

Dilihat dari gambar denah Mihrab dan Mimbar berada di bagian tengah dan di seimbangi oleh ruang solat kanan dan kiri yang memilki bentuk yang hampir sama. Sesuai dengan aturan yang sudah di sabdakan oleh hadist nabi Diriwayatkan dari Abu Hurairah katanya: Rasulullah saw besabda: "Jadikan imam di tengah (shaf) dan penuhilah (saf) yang kosong".[HR. Abu Dawud] (Yahya, 2008).

c. Tempat Wudhu

Tempat wudhu pada Masjid Cipaganti ini di pisah antara tempat wudu lakilaki dan perempuan,karna di khawatirkan terjadi pencampuran antara Laki-laki dan Perempuan (Syamsul Kurniawan, 2014).

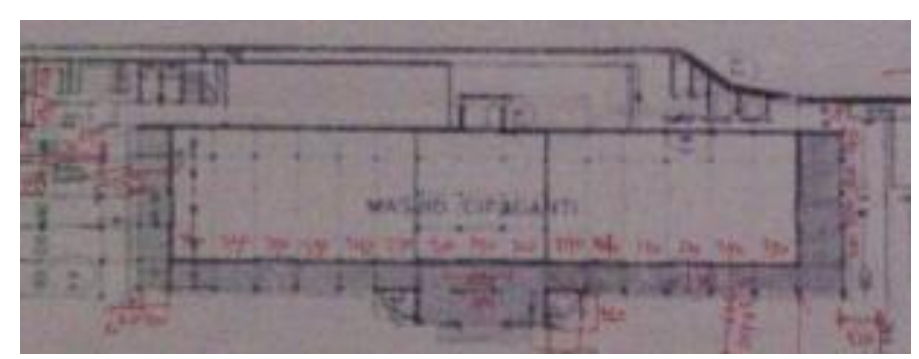

Gambar 8. Denah Masjid dan posisi perteltakan tempat Wudhu. Sumber: Dokumentasi DKM Masjid Cipaganti

Untuk sirkulasi dan pintu masuk nya juga di bedakan dari tempat wudhu Lakilaki dan Perempuan (Dwi Kustianingrum, 2012). 


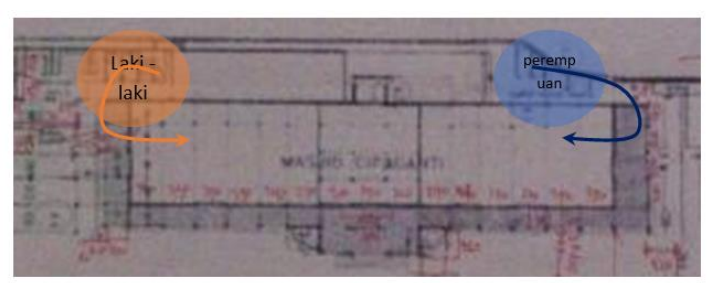

Gambar 9. Denah Dan Alur Sirkulasi dari tempat Wudhu. Sumber: Dokumentasi DKM Masjid Cipaganti

d. Serambi Masjid

Pada bagian serambi Masjid Cipaganti ini merupakan ruang luar yang memilii fungsi sebagai berikut untuk bagian samping kanan dan kiri di fungsikan sebagai akses masuk ke dalam masjid melalu pintu kanan dan kiri dan di sebelah pintu masuk itu ada tempat untuk penitipan barang yang dimana tempat itu di bagi dua yaitu pada bagian selatan khusu untuk laki laki dan bagian utara khusus untuk perempuan. dan pada bagian serambi depan masji ini di fungsikan sebagai tempat untuk berinteraksi sosial dan beristirahat (Masdar Farid, 2013).

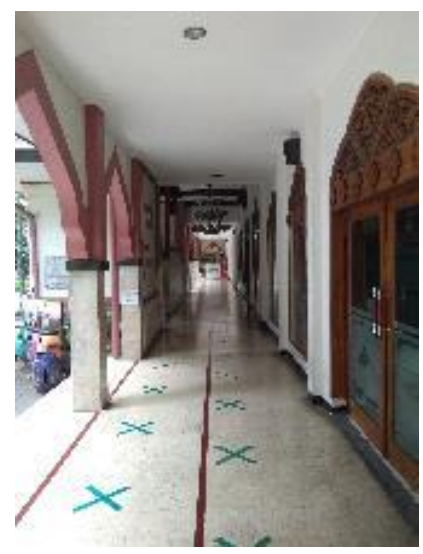

Gambar 10. Serambi Masjid. Sumber: Dokumentasi DKM Masjid Cipaganti

e. Ornamen pada bagian luar dan dalam

1) Ornamen pada bagian luar

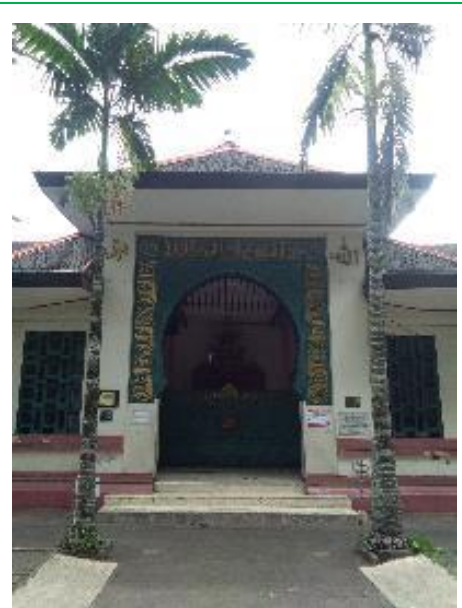

Gambar 10. Kaligrafi pada bagian depan Fasad Masjid. Sumber: Dokumentasi Pribadi 
Capaian kinerja Bidang Perhubungan tersebut dicapai melalui program dan kegiatan sebagai berikut.(Andiyan, Rachmat, 2021b) Pada bagian fasad utama Masjid Cipaganti ini menggunakan ornamen kaligrafi bahasa arab yang bertuliskan Laillahaillah yang terlihat di sisi kiri ,kanan dan bagian atas gawangan yang berwarna hijau dan untuk kolom yang berada di kanan dan kiri itu terdapat kaligrafi yang bertuliskan Allah pada bagian kana dan Muhammad pada bagian kiri .dan pada dinding sekat yang berada di belakang gawangan dan di depan pintu masuk utama terdapat kaligrafi bahasa arab yang mengkutip dari ayat Al-Quran yang bercerita tentang orang orang yang memakmurkan Masjid.(Umar, 2014)

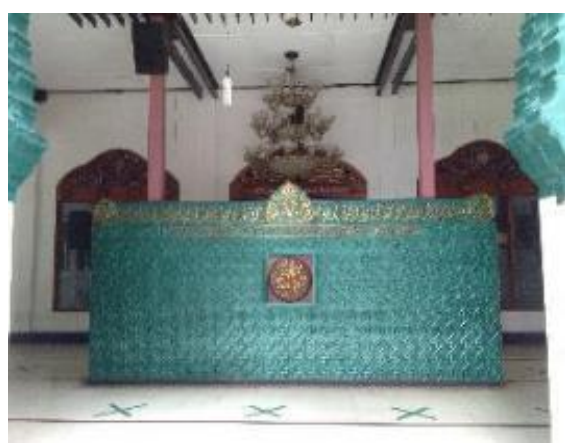

Gambar 11. Kaligrafi pada Dinding Pemisah. Sumber: Dokumentasi Pribadi

2) Ornamen pada bagian dalam

Ornamen pada bagian dalam masjid ini cukup banyak terutama pada bagian ruang solat hampir sekeliling dinding ruang dalam memiliki kaligrafi bahasa arab.( Fracis D K CHING, 2008,. Andiyan,Nurrisman, 2021) Seperti gambar di bawah ini:

Gambar 12. Kaligrafi Pada bagian Kolom. Sumber: Dokumentasi Pribadi 


\section{Gambar 13. Kaligrafi pada kusen bouvenlight. Sumber: Dokumentasi Pribadi}

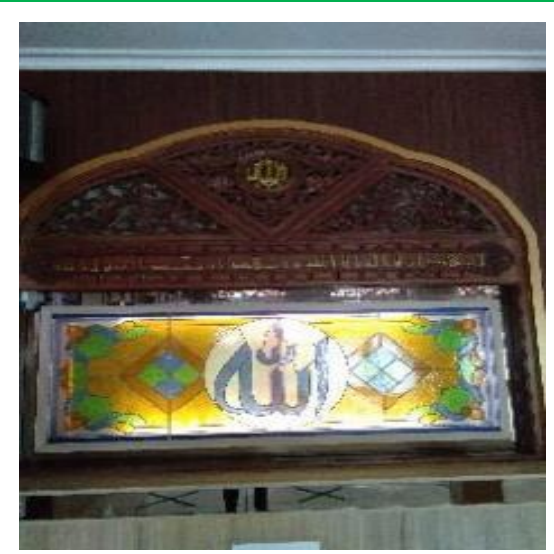

Gambar 14. Kaligrafi Pada Dinding. Sumber: Dokumentasi Pribadi

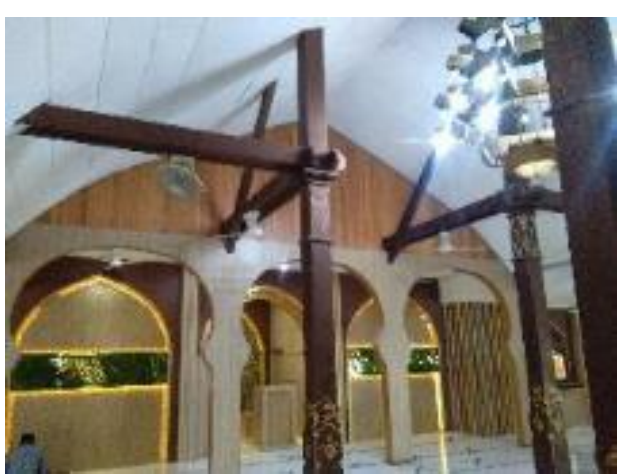

Gambar 15. Kaligrafi Pada kanan Kiri Mihrab. Sumber: Dokumentasi Pribadi

Adanya ornamen kaligrafi pada bangian dalam dan luar bangunan adalah sebagai sarana untuk mengingatkan manusia terhadap tuhan nya. Karna biasa nya kaligrafii arab atau kaligrafi islam bertuliskan nama Allah dan Rasul nya Muhammad dan juga kutipan dari ayat- ayat Al-Quran (Al Buthy, 2010).

\section{Kesimpulan}

Dari hasil analisa dan pembahasan Masjid yang memiliki satu massa bangunan cagar budaya dan satu massa bangunan baru ini memiliki pengaruh 
Arsitektur Islam yang cukup kental dari mulai bentuk massa bangunan ,Orientasi bangunan, fungsi elemen ruang dan ornamen kaligrafi bahasa arab yang kental pada bagian dalam dan luar bangunan yang cukup sesuai dengan aturan-aturan Islam dan prinsip- prinsip Arsitektur Islam .

Maka dapat di tarik kesimpulan bahwa massa bangunan Masjid Cipaganti sudah sesuai dengan aturan Arsitektur Islam yang berlaku karna menurut Utaberta arsitektur Islam adalah sebuah pendekatan arsitektur dengan berusaha melihat ke dalam sistem nilai yang ada dalam Islam untuk kemudian diterapkan ke dalam perancangan bangunan.

\section{Daftar Pustaka}

Al Buthy, M. S. R. (2010). Sirah Nabawiyah: Analisis IImiah Manhajiah Sejarah Pergerakan Islam di Masa Rasulullah Saw. Rabbani Press.

Andiyan, Indra, F. (2018). Penataan kawasan kumuh (kewenangan provinsi) di desa tanjung anom kecamatan mauk kabupaten tangerang. Jurnal Arsitektur Archicentre.

Andiyan, Rachmat, A. (2021a). Analisis Manfaat Pembangunan Infrastruktur Kereta Api Di Pulau Jawa. Jurnal Pendidikan Dan Teknologi Indonesia, 1(3), 121-129.

Andiyan, Rachmat, A. (2021b). Telaahan Kerjasama Pemerintah Swasta Dalam Pembangunan Bandara Kertajati Di Jawa Barat. Aksara: Jurnal IImu Pendidikan Nonformal, December 2017, 413-424.

Andiyan,Nurrisman, O. (2021). Implementation of the New Function of the Sarinah Braga Building ( Hotel De Braga By Artotel ). Solid State Technology, 7.

CHING, F. D. K. (n.d.). Bentuk, Ruang Dan Tatanan.

Dwi Kustianingrum, F. S. dkk. (2012). Kajian Tatanan Massa Dan Bentuk Bangunan Terhadap Konsep Ekologi Di Griyo Tawang. Library Itenas.

Irawan, R. F. S., \& Muqoffa, M. (2019). Penerapan Islam Pada Perancangan Islamic Center Kabupaten Brebes. Jurnal Senthong, 2(1).

Masdar Farid. (2013). Kaligrafi dalam Sejarah Peradaban Islam. Republika.

Mujab, S. (2014). Kiblat Dalam Perspektif Madzhabmadzhab Fiqh. Yudisia, 5(2).

Rapoport, A. (1969). House Form and Culture. Prentice Hall Inc.

Sugiyono. (2014). Metode Penelitian Kuantitatif, Kualitatif, dan Kombinasi (Mixed Methods). In Metode Penelitian Kuantitatif, Kualitatif dan R\&D. https://doi.org/10.3354/dao02420

Syamsul Kurniawan. (2014). Masjid Dalam Lintasan Sejarah Umat Islam” Jurnal Khatulistiwa. Journal of Islamic Studies.

Tiaratanto, Excya,Affandi,Kemal, A. (2021). Bangunan konvensi dan eksibisi bandung. Jurnal Arsitektur Archicentre, 126, 1-13.

Umar. (2014). Integrasi Konsep Islami Dan Konsep Arsitektur Modern Pada Perancangan Arsitektur Masjid. Radial - Jurnal Peradaban Sains, Rekaysa Dan Teknologi Sekolah Tinggi Teknik (STITEK) Bina Taruna Gorontalo. 
Utaberta, N. (2007). Permasalahan dan Pendekatan Studi Tentang Arsitektur Islam. Jurnal IImiah Desain Dan Konstruksi Universitas Gunadarma, 2(6).

Yahya, A. (2008). Arsitektur Islam: Seni Ruang dalam Peradaban Islam Wawasan Al-Qur'an oleh Dr. M. Quraish Shihab, M.A.

https://luk.staff.ugm.ac.id/kmi/islam/Quraish/Wawasan/Masjid.html 